Article

\title{
Could CSR Practices Increase Employee Affective Commitment via Moral Attentiveness?
}

\author{
Seher Uçkun ${ }^{1}$, Aykut Arslan ${ }^{2, *}$ and Serdar Yener ${ }^{3}$ (D) \\ 1 Kandıra Vocational School, Kocaeli University, Kandıra, 41600 Kocaeli, Turkey; uckun@kocaeli.edu.tr \\ 2 Faculty of Economics and Business, Piri Reis University, Istanbul, 34940 Tuzla, Turkey \\ 3 Faculty of Economics and Business, Sinop University, Sinop, 57000 Boyabat, Turkey; \\ serdaryener@sinop.edu.tr \\ * Correspondence: aarslan@pirireis.edu.tr
}

Received: 8 September 2020; Accepted: 2 October 2020; Published: 5 October 2020

check for updates

\begin{abstract}
The impact of corporate social responsibility (CSR) activities on companies' macroeconomic indicators (financial performance, sustainability) has been the subject of many studies. However, more recently, the effect of CSR activities on individual variables (microeconomic indicators) has begun to attract attention. Although CSR itself is founded on the moral roots of the society in which it operates, it seems that the effect of individuals' moral attentiveness has been neglected. The CSR effect, which is the focus of this study, is examined using three dimensions to understand how CSR can directly and indirectly affect the organizational commitment of employees. A theoretical model is developed in this paper, the focus of which is on the ethical framework of CSR and the proposition that it may have an effect on employees. The sample comprises individuals working in two of the country's most important private production facilities in the western capital of Turkey. An online questionnaire form was prepared and shared. The online form was active between 2 March 2020 and 11 May 2020. Out of 472 forms, 465 were usable and, therefore, used in the analyses. We found proof for most of our assertions. Implications and future research suggestions are discussed.
\end{abstract}

Keywords: CSR; moral attentiveness; employee affective commitment; Turkey

\section{Introduction}

Sustainability, a must-have feature of businesses, has been defined as meeting today's expectations and goals without using the resources of the future [1]. Sustainable growth is seen as a process of generating value consisting of financial, environmental, and social components [2]. Today, social responsibility is considered the causal factor of the progress that businesses must make to achieve sustainability [3,4]. Today, businesses operate in an environment where internal and external stakeholders have more social and environmental awareness, and their expectations are now, therefore, higher. Businesses that can meet these expectations are preferred because they can meet the needs of more stakeholders. In return, this provides a sustainable competitive advantage. That social and environmental responsibility behaviors are increasing businesses' sustainable competitive advantage is not a new argument [5]. Regarding the function of corporate social responsibility (CSR) activities in businesses, the literature dates back to the 1950s [6]. At that time, the impact of CSR activities on macroeconomic indicators (financial performance, sustainability) of companies came to the fore, while the effect of CSR activities on individual variables as microeconomic indicators has become the subject of studies in recent years [7,8]. Since the 1960s, it has been strongly argued by CSR researchers that companies can yield profits through these activities [9]. For example, Orlitzky et al. [10] found support for this view in their meta-analysis study. Around 34,000 observations from 52 studies revealed that CSR behaviors affect the financial sustainability of businesses more than other antecedents. 
Nevertheless, many studies showing that macroeconomic indicators can be affected by microeconomic indicators have opened new avenues in CSR research. One example is Porter and Kramer's [11] shared value approach, which assumes that companies, as agents of social change, can achieve both social progress and business success simultaneously. In another example, the process of redefining the value chain has helped to integrate topics such as environmental impact, employee skills, worker safety, employee health, and water and energy use [12]. It has long been argued that business policies that encompass employee health, safety, and personal development can enhance employee loyalty and performance, thus improving profits [13]. For example, it has been reported that the social responsibility activities of the Levi's brand regarding the well-being of employees, the living standards of the employees of the Patagonia brand, and the health of the employees of the Johnson \& Johnson brand have yielded millions of dollars in the mid-term. This debate that tries to reconcile opposing point of views with regard to materialistic (strategic, profit-making) versus moral aspects of CSR is still a hot topic in the literature [14].

CSR activities are classified into two main categories. One is targeted at external stakeholders (society and environment), whereas the other is targeted at internal stakeholders (mostly employees). A successful CSR strategy should be embedded in the organizational core competencies and integrated within the firm's strategy, routines, and operations [15], including HR. However, there is still ambiguity concerning the understanding of the microfoundations of CSR [16-18], particularly mechanisms that explain the underlying effects of how CSR activities are perceived by the employees [16-18]. Studies have claimed that employee perceptions towards CSR practices may affect employees' subsequent behavior towards the organization [16,19]. For example, the effects of practices and policies in organizations on employee commitment have been revealed in many studies that have addressed the relationship between CSR and employee commitment [20]. However, although strong relationships have been observed in most of the studies regarding this relationship, there are very few studies that reveal the mechanism by which this relationship occurs by examining specific cases [21]. Examples of such studies include Wurthman [22], Kim et al. [23], and Afsar and Umrani [24]. These scholars tried to shed light on how the moral aspects of individuals in organizations affect their perception of CSR and if any changes occur regarding their attitudes. However, in all of these studies, only one dimension of moral attentiveness was discussed. Interestingly, the perceptual dimension has not been the subject of much empirical research. Reynolds [25] defined moral attentiveness as a two-dimensional concept. It involves two aspects of human attention: at the perceptual level, information is automatically processed as it is encountered; at the reflective level, the individual uses morality to reflect on and examine her/his experience. CSR in this study is conceptualized as a three-dimensional construct (CSR related to employees, to society, and to the natural environment). Thus, the aim of this study is to find out how these three dimensions of CSR could relate to the two aspects of moral attentiveness and, through moral attentiveness, how CSR could affect the organizational commitment of the employees.

Therefore, one of the contributions of this study to the literature is that it addresses the concept of moral attentiveness using two dimensions. The second contribution is the moral effect of CSR on employees and whether it creates affective commitment indirectly through this effect. By this, we intend to contribute to the debate by focusing on the moral foundations of CSR. Social cognitive theory is used to explain the relationships in the theoretical model. Thus, by responding to the calls for further research $[21,26,27]$ regarding the mechanisms by which CSR activities can affect the behavior of employees, new findings and new methods regarding how CSR activities are perceived are presented and, thus, fill the gaps discussed above.

\section{Literature Review and Hypothesis Development}

\subsection{CSR and Affective Commitment}

An increasing number of studies have shown that businesses need to use their employees' talents and skills more effectively in order to achieve sustainable competitive advantage $[28,29]$. In this 
respect, employee commitment is cited as one of the main determinants of sustainability in today's volatile and uncertain business environment [30]. Employee commitment is a tripartite concept (continuance, affective, and normative commitment) and expresses the commitment of the individual to the organization [31]. Affective commitment is determined by schemas shaped by the cognitive processes formed by the individual's observations and experiences [32]. It has been reported that individuals with high affective commitment are emotionally identified with their businesses and show a high participation in business processes [14,19]. Employees' desire for the well-being of their organization has been reported as an indicator of affective commitment [33]. When compared to continuance commitment and normative commitment, a stronger employee desire has been observed for affective commitment [16].

In the studies conducted, strong relationships have also been observed between affective commitment and employee well-being and performance [8,34]. Additionally, scholars argue that the physical, emotional, and mental commitment of the employees are the tools that every leader needs to achieve the goals of the organization [30,35]. Meyer and Maltin [34] stated that an employee environment that meets the expectations of employees will create affective commitment and psychological well-being in employees. In the studies of Kanter [35] and Sheldon [36], it was found that the level of social interaction with the organization of the individual is an indicator of her/his affective commitment. It has also been asserted that individuals become alienated in organizational environments in which they do not interact or participate in social interaction, and that when they interact, they become identified by showing emotional attachment [37]. It is thought that the level of adaptation of individuals with their organizations depends on the fit between their individual expectations and needs, organizational practices, and interpersonal relations [30]. Increasing this level of adaptation can enable the individual to participate more or, in other words, increase affective commitment. For example, in a recent study, Bouraoui et al. [18] found that employees' perception of CSR (based on how well they perceive the fit with their organizations) can determine their affective commitment. When the effects of organizations' CSR practices on the organizations' stakeholders are compared, the level of observation or influence of all other stakeholders except employees can be indirect [38]. Employees are directly affected by organizations' CSR through their wages, personal development, occupational health and safety, and their contributions to the society they live in [37]. Further, CSR practices in these areas can create positive feelings in employees, which can change the perspective of the employees both institutionally and individually [38]. It is believed that employees evaluate the CSR activities of businesses on a voluntary basis by comparing them with other businesses. When this evaluation is positive in favor of the company they work for, they may have positive feelings towards their business [37]. Within the scope of CSR practices, companies may neglect other areas, potentially turning to CSR activities in only one area, i.e., only education, personal development, wages, etc. This might be seen as neglecting other areas or environmental responsibilities. There may be employees who may be affected by the areas that businesses address due to their different characteristics, or there may be employees who may be negatively affected by neglected areas, resulting in negative feelings.

Another approach that suggests that CSR activities can create employee commitment in employees is the approach based on deontic theory [9]. The deontic approach proposes that individuals' behaviors within the organization will affect their fairness perceptions within the organization [39]. Stating that CSR practices in organizations shape employees' perceptions of organizational justice, Rupp et al. [19] asserted that employees will have positive feelings in fair organizations. In the process of evaluating their organization, employees compare what is received by and given to all stakeholders and, when they act fairly as an organization in this relationship, an ethical perception can be formed [8]. In other words, indicators such as the level of satisfaction of the employees when the organization gains income thanks to its employees, which is the production factor or the level of meeting the expectations of the organization's market and the environment in which it operates, shape the perceptions of the employees. Likewise, Turker [40] claimed that the sustainability of organizations is based on their relations with the public environment, employees, customers, and the natural environment. 
In summary, it is thought that organizations can create positive emotions, i.e., commitment, by satisfying employees when CSR activities meet the expectations and needs of employees. On the other hand, we claim that employees, as internal stakeholders, can closely observe, compare, and evaluate the CSR activities of the organization towards society, the natural environment, customers, and employees within the framework of ethical perception. When the result of this evaluation is positive, positive emotions, i.e., the perception of employee commitment, can develop. Therefore, the following hypotheses are posited:

H1. CSR has a direct effect on employee affective commitment.

H2. The relative importance of direct predictors (sub-factors of CSR: CSR related to employees; CSR related to society; and CSR related to the natural environment) of employee affective commitment will be different.

\subsection{CSR and Moral Attentiveness}

It is assumed that the moral attitudes and behaviors of employees in today's business environment, which is becoming increasingly complex and ambiguous, can be shaped by different determinants. This is because the environments in which businesses operate vary and each sociocultural area has different priorities. It has been argued that individuals can also make different moral generalizations in different environmental and sociocultural areas [22]. In addition, it has also been claimed that the ethical practices of organizations with different missions in many areas of society can create synergy by ensuring that employees have positive feelings [41].

An important function of CSR activities for organizations stems from the moral responsibilities of organizations in society [42]. Considering that social responsibility discussions are increasing in today's business world, what should be done about the responsibilities of organizations towards their employees, society, and the natural environment, and what kind of consequences these actions can have on different social layers have been the subject of many studies [40]. The point to note here is the moral dimension of CSR practices. The discussions on this subject are based on the understanding of companies as the basic components of society, as they operate by using the resources and opportunities of the society they are in. It is an undeniable reality that businesses that sustain themselves by taking their resources from the natural environment and society and by presenting their products to society have responsibilities towards the natural environment and society. Therefore, it has been claimed that businesses are moral agents, as the basic components of society; this situation, however, has been criticized and it has been argued that CSR has been transformed into a tool that serves political purposes [43]. However, addressing the sustainability issue via social stakeholders in terms of ethics and morality, rather than economic reasons, can lead to more effective results [44].

CSR is basically conceptualized in terms of employees, society, and the environment [40], and it can affect employees' attitudes and behaviors differently [45]. Although Kohlberg's studies on the moral behavior of the individual have also been examined within the framework of behavioral psychology in the 1950s, they have been used extensively as a reference since the 1970s [46]. In the behavioral approach, it is assumed that individuals develop moral norms by internalizing the behaviors and norms of the societies they live in, and that they can create moral attention within the framework of these norms.

Reynolds [25] (p. 1028) described moral attentiveness as "the extent to which an individual chronically perceives and considers morality and moral elements in his or her experiences." The moral attentiveness of individuals is formed as a result of stimuli and individual-environment interaction [22]. In this process, the characteristics of the stimulus, such as accessibility, vividness, and saliency, affect the individual's perception of the stimulus, the encoding of the message, and the attention paid based to the incoming information [47]. When CSR practices are evaluated as a stimulus, saliency, vividness, and accessibility features can be considered to affect the individual's perception, encoding, and attention related to CSR practices. From the point of view of saliency, it can be considered that CSR activities related to the expectations and wishes of the employees as stakeholders may attract their attention. 
This situation, which is also related to the saliency feature of CSR practices, suggests that different expectations and needs of individuals may lead to them evaluating their CSR practices differently [48]. This situation causes two employees working in the same organization to evaluate CSR practices differently. In other words, it can be considered that CSR activities that fit with the expectations and needs of individuals may attract more attention. The fact that CSR activities cover applications to meet changing demands in a complex and variable environment can be an indicator of the vividness of CSR practices.

Reynolds [25] claimed that moral attentiveness consists of two dimensions (perceptual and reflective). The perceptual moral attentiveness process concerns the rapid evaluation of situations and events through an ethical lens based on the moral schemes (chronic accessibility) previously created. In the reflective moral attentiveness dimension, determinants such as contextual factors and personal experiences are effective and lead to situational evaluations [25]. Reflective moral attentiveness is effective in ethical cognitions and schema formation [22]. In addition, individuals evaluate the situations they encounter in terms of moral attention and try to infer meanings that will shape their cognitive processes [49]. This creates an ethical lens by transforming these meanings into generalizable information. Since experience and knowledge create chronic accessibility, individuals can instantly evaluate and make sense of the situations they encounter. In addition to the duties and responsibilities of employees within the organization, moral attention also affects the behavior of the organization towards other stakeholders, especially customers [22,50]. Cognitive schemas created by the individual based on past experience and knowledge can enable the individual to evaluate stimuli by improving their chronic accessibility [25]. Individuals' cognitive schemes enable them to react suddenly to stimuli using chronic accessibility. In other words, the more moral schema the individual has created in the past, the better his/her chronic accessibility develops and the faster he/she can react to the situations encountered.

When determining the CSR practices of companies, considering the expectations of employees and other stakeholders and prioritizing CSR practices accordingly, this may attract the moral attention of employees. For example, consider a business where family-work balance is not possible. If the priority of the employees in this business is family-work balance, it is thought that the improvement of resting facilities or occupational health-and-safety practices in the workplace will not have a great impact on these employees. Since the family is one of the most important areas in the lives of individuals generally, it is a priority for most individuals [51]. Because these employees think that a business that distances them personally from their families is not ethical in today's world, and they work there because they are obliged to, they may perceive that the business has working conditions outside of their moral standards. In other words, considering that almost every employee can have a priority in CSR practices, it is argued that they can develop a low or high level of reaction to each CSR practice they encounter. Therefore, in order to be suitable for the study, we tried to include different responses by considering CSR in three dimensions.

The moral attentiveness feature alone may not be enough to create emotion and reaction in individuals. Organizations' practices that glorify and reward moral behaviors help individuals to spread moral norms and behaviors by internalizing them [25]. In this respect, organizations can engender the internalization of moral attention by sending signals that can trigger moral attention in their mission, vision, policy, and value definitions, and supporting them with real practices within the organization (e.g., CSR practices) [52]. It is thought that the accessibility, vividness, and saliency features of CSR can enable individuals to create the dimension of reflective moral attentiveness and thus create reactions with a perceptual moral attentiveness dimension by creating an ethical lens. Since the positive outcomes of these reactions can have an emotional effect, they may also shape employee commitment. Therefore, the following hypotheses are posited:

H3. Employees with high moral attentiveness will be more affected by CSR practices in general than those with low moral attentiveness. 
H3a. Employees with high moral attentiveness will be more affected by CSR practices related to employees than those with low moral attentiveness.

H3b. Employees with high moral attentiveness will be more affected by CSR practices related to society than those with low moral attentiveness.

H3c. Employees with high moral attentiveness will be more affected by CSR practices related to the natural environment than those with low moral attentiveness.

H4a. The effect of CSR related to employees, society, and the natural environment on perceptual moral attentiveness will be different with regards to relative importance.

$\mathbf{H} 4 \mathbf{b}$. The effect of CSR related to employees, society, and the natural environment on reflective moral attentiveness will be different with regards to relative importance.

\subsection{The Role of Moral Attentiveness as a Mediator Between CSR Practices and Affective Commitment}

It has been argued that individual expectations and desires may also vary according to individual differences [53]. In this context, Kohlberg [54] suggested that moral behavior can be affected not only by social norms but also by individual characteristics. Kohlberg believed that, by developing a three-level and six-stage model, individuals make rational decisions that will shape their feelings and behaviors by comparing their personal interests, social norms, and interests. Rest's [53] four-stage model proposes that individuals have cognitive processes based on moral sensitivity, moral judgment, moral motivation, and moral character levels. The moral judgment stage is perhaps the most important stage in shaping cognitive processes. At this stage, it is assumed that individuals use their past experiences to make the right decision in complex and uncertain situations they encounter [53]. At this stage, it is also assumed that past experiences can lead to intense emotions in individuals in response to situations they encounter [53]. This perspective also seems to form the basis for Reynolds's point of view regarding moral attention. Kohlberg's process in the moral judgment stage describes the process experienced by the individual in Reynolds's reflective dimension. In both approaches, it can be considered that the cognitive process for moral consideration is in place and perspectives for future evaluation and judgment are formed. It is thought that events stimulating cognitive processes can form ethical lenses and lead to instant emotional or behavioral responses, thanks to the moral schemes shaped by the experiences of the individual. This constitutes the perceptual dimension of Reynolds's [25] definition of moral attention. In this respect, the cognitive schemas of people who have been exposed to intense moral experiences in the past will be more developed, and their moral attention may be higher. The reactions they will have to the applications and situations they encounter naturally (e.g., CSR practices) will also include feelings and behaviors in accordance with their moral codes. The moral attention of these employees will also become higher and more intense than others. Therefore, the emotions they will experience when faced with CSR practices, in line with their moral expectations, may be intense and positive. As a result, it is thought that employees will develop more positive feelings towards their organizations. Affective commitment to the organization can be one of the strongest positive emotional reactions. Therefore, the following hypothesis is posited:

H5. The affective commitment of employees with high moral attentiveness will be higher than those with lower moral attentiveness.

Instead of full mediation, we propose that moral attentiveness could act as a partial mediator between CSR practices and affective commitment. According to Holland et al. [55], to justify a full mediation, we need to require more than justification of the proposed mediating mechanism. In other words, to discuss why the effect of $X$ on $Y$ is transmitted through a mediator may not suffice and, hence, when we extract the mediator from the relationship, "there is little reason for an $\mathrm{X}-\mathrm{Y}$ relationship to exist" [55] (p. 695). While providing very particular evidence for that, one should also prove that the mediator is the primary reason for the relationship. To sum up, it is extremely difficult to find 
a full mediation in these relationships $[55,56]$. Bearing these reflections in mind, we propose partial mediation, leading to the following hypotheses:

H6a. Reflective moral attentiveness will act as a partial mediator between CSR related to employees and affective commitment.

H6b. Reflective moral attentiveness will act as a partial mediator between CSR related to society and affective commitment.

H6c. Reflective moral attentiveness will act as a partial mediator between CSR related to the natural environment and affective commitment.

H6d. Perceptual moral attentiveness will act as a partial mediator between CSR related to employees and affective commitment.

H6e. Perceptual moral attentiveness will act as a partial mediator between CSR related to society and affective commitment.

H6f. Perceptual moral attentiveness will act as a partial mediator between CSR related to the natural environment and affective commitment.

The study model is shown as Figure 1.

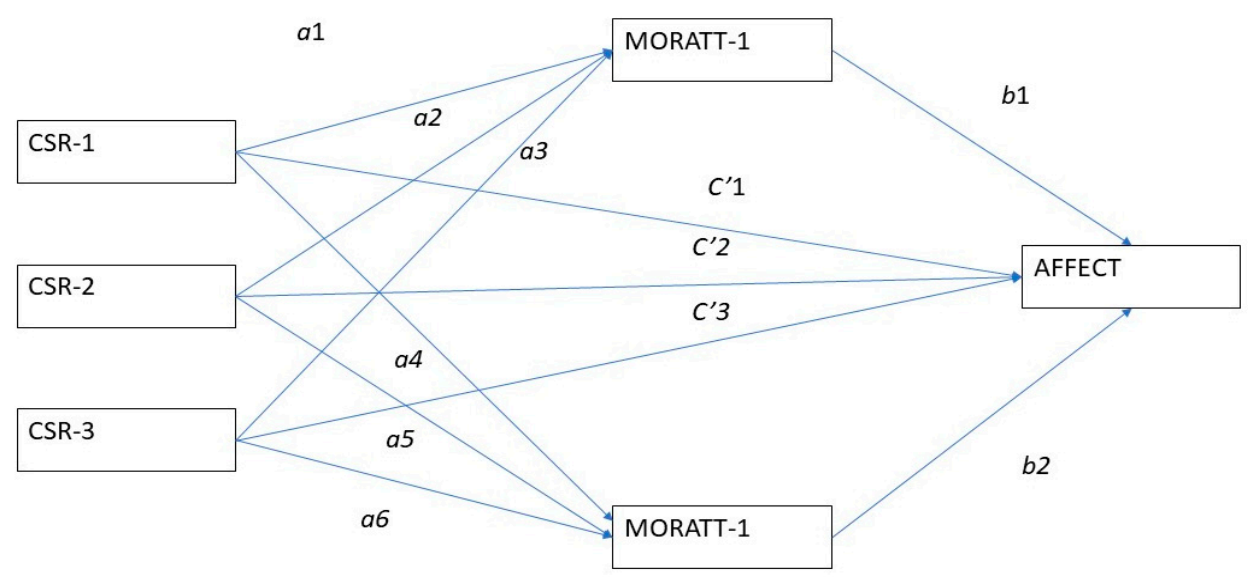

Figure 1. The study model.

\section{Method}

The sample comprises employees working in two of the country's most important private production facilities in the western capital of Turkey. We contacted HR managers of both factories and received their consent. Afterwards, an online questionnaire form was prepared and shared. The online form was active between 2 March 2020 and 11 May 2020. To avoid confirmation bias, we followed time-lagged procedures. The first and last forms were put online initially. Then, after six weeks, we asked them to fill in the moral attentiveness scale. Among 472 forms, 465 were usable and, therefore, used in the analyses. For data analysis, we employed SPSS 23 and PROCESS macro 3.1. All the scale items were measured using a five-point Likert scale from $1=$ "strongly disagree" to $5=$ "strongly agree."

\subsection{Definitions of the Variables}

CSR: context-specific actions and policies that aim to enhance the welfare of stakeholders by accounting for the triple bottom line of economic, social, and environmental performance, with a focus on employees' perceptions of CSR [57] (p. 5).

CSR related to employees: CSR activities targeted at employees directly and indirectly (i.e., HR activities such as training and development, career management, etc.). 
CSR related to society: CSR activities that benefit society the most.

CSR related to the natural environment: CSR activities targeted at the natural environment for protection, improvement, and development.

Moral attentiveness: a concept that involves two aspects of human attention: at the perceptual level, information is automatically processed as it is encountered, whereas at the reflective level, the individual uses morality to reflect on and examine her/his experience [25].

Affective commitment: emotional attachment to and involvement in the organization among its employees [57].

\subsection{Sample}

The sample was mainly male (70.1\%). The majority of the employees were young (age groups $18-25(28 \%)$ and $26-33(34 \%))$. Almost half were married $(47.5 \%)$, and $43.2 \%$ of the sample were unexperienced. Finally, $81.7 \%$ of our contributors were employees. Full demographic details are provided in Table 1.

Table 1. Demographics.

\begin{tabular}{cc}
\hline Demographic Variable & Percentage \\
\hline Gender & \\
Male & 70.1 \\
Female & 29.9 \\
\hline Age (years) & \\
$18-25$ & 28 \\
$26-33$ & 34 \\
$34-41$ & 21.1 \\
$42-49$ & 13.1 \\
$50+$ & 3.9 \\
\hline Status & \\
Employee & 81.7 \\
Foreman & 18.3 \\
\hline Marital Status & $\%$ \\
Married & 47.5 \\
Single & 52.5 \\
\hline Tenure (years) & \\
$1-2$ & 43.2 \\
$3-4$ & 18.5 \\
$5-6$ & 13.8 \\
$7-8$ & 4.7 \\
$9+$ & 19.8 \\
\hline &
\end{tabular}

\subsection{Scales}

CSR was measured using the scale of Turker [40], who kindly shared the Turkish version with us. The original scale comprises 18 items. We used only CSR related to employees (five items; $\alpha=0.92$ ), CSR related to society (two items; $\alpha=0.88$ ), and CSR related to the natural environment (two items; $\alpha=0.89$ ) (example item: "Our company supports those employees who want training").

Moral attentiveness was measured using the scale of Reynolds [25]. It consists of 12 items (example item: "I regularly think about the ethical implications of my decisions") (perceptual $\alpha=0.84$; reflective $\alpha=0.71$ ).

Employee affective commitment was measured using the scale of Allen and Mayer [58]. We used three items from the original scale (example item: "I feel personally attached to my organization") $(\alpha=0.79)$. 


\subsection{Control Variables}

For the control variables, we used various demographic variables (age, marital status, gender, and work experience of the employees) because prior research has shown significant relationships between these demographic characteristics and ethical issues [59].

As for the results of control variables, age groups seem to affect the perceptual ( $\beta=-0.27 p<0.000$ for CSR-1 model; $\beta=-0.26 p<0.000$ for CSR-2 model; $\beta=-0.25 p<0.000$ for CSR-3 model) and reflective moral attentiveness ( $\beta=-0.18 p<0.001$ for CSR-1 model; $\beta=-0.17 p<0.01$ for CSR-2 model; $\beta=-0.16 p<0.01$ for CSR-3 model) negatively and significantly. However, when the age groups are included in the mediation models, their effect becomes insignificant. The other control variables have no effect at all.

\subsection{Measurement Reliability}

Table 2 lists the descriptive statistics, inter-scale correlations, and reliability estimates (Cronbach's alphas on the diagonal). All scales were internally consistent. While CSR is largely correlated with affective commitment, moral attentiveness is moderately correlated. Finally, moral attentiveness significantly correlates with CSR, but the association is small.

Table 2. Descriptive statistics and inter-scale correlations.

\begin{tabular}{ccccccc}
\hline & & Mean & SD & $\mathbf{1}$ & $\mathbf{2}$ & $\mathbf{3}$ \\
\hline 1 & AffCom & 3.48 & 0.99 & 0.79 & & \\
2 & CSR & 3.80 & 0.90 & $0.659^{* *}$ & 0.95 & \\
3 & MorAtt & 3.31 & 1.02 & $0.348^{* *}$ & $0.226^{* *}$ & 0.85 \\
\hline
\end{tabular}

** $p<0.001$ (two-tailed). $n=449$. AffCom = employee affective commitment; CSR = corporate social responsibility; MorAtt $=$ moral attentiveness.

\subsection{Measurement Validity}

To determine the validity of the scales, we ran confirmatory factor analyses (Table 3). Confirmatory factor analysis supported the original three-factor structure for CSR $\left(\chi^{2}=84.3, \mathrm{df}=24\right)$, a two-factor structure for moral attentiveness $\left(\chi^{2}=19.16, \mathrm{df}=8\right)$, and a one-factor structure for employee affective commitment $\left(\chi^{2}=145, \mathrm{df}=30\right)$. As for the discriminant validity, AVE (Average Variance Extracted) and CR (Composite Reliability) values were calculated. AVE values are above 0.50, and CR values are above 0.70 indicating discriminant validity, and all the values of scales are above these thresholds. Thus, the data fit well and we continued with hypothesis testing.

Table 3. Confirmatory factor analyses of the scales.

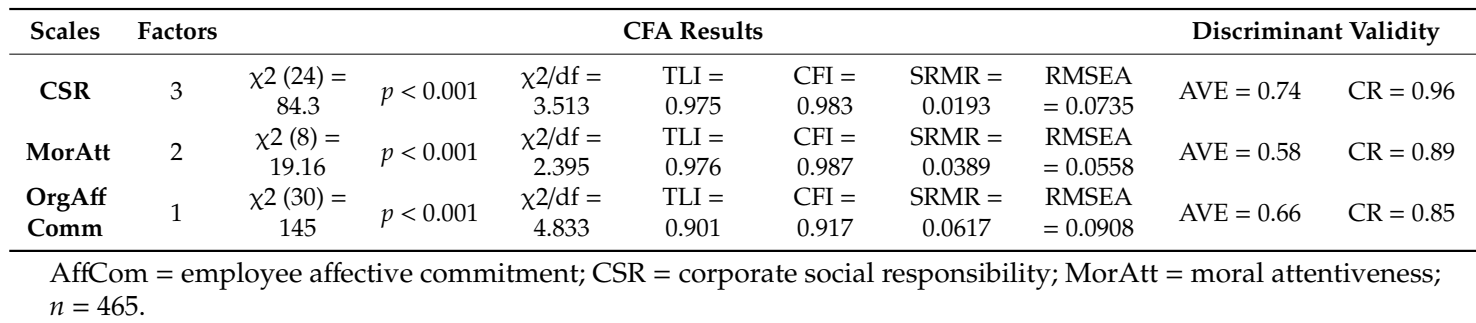

\section{Hypothesis Testing Results}

In our first hypothesis, we predicted that CSR practices have a direct effect on employees' affective commitment. In order to test this assertion, we ran a simple regression analysis. The results confirmed our hypothesis ( $\beta=0.66, p<0.001,95 \%$ CI $0.53-0.65$ ). To test the second hypothesis, we ran a dominance analysis. This type of analysis was introduced by Budescu [60], and the aim is to put the regressors into a rank order to find improvements in the fit of the model [61]. The analysis is based on how one regressor, comparatively with another, adds to increasing $R$, which equates to the amount of the variance in $Y$ that 
a regressor explains or how much it decreases the error of the estimation. The coefficients of traditional regressions represent the amount of unique variance predicted by any one predictor. This means that, if the predictors are correlated, then regression coefficients do not adequately represent how well one predictor does relative to all combinations of the other predictors [62]. The results are provided in Table 4 . The numbers in the table represent the average $\Delta \mathrm{R}^{2}$ of the focal predictor when added to regression equations with different sub-sets of the other predictors. All the predictors contribute to employees' affective commitment differently, thus supporting H2. Notably, CSR-1 (CSR related to employees) has the largest dominance value (39\%) for each sub-set of models. This means that the completely dominant regressor adds more to prediction accuracy or explaining variance in $Y$ than does any regressor it completely dominates; thus, it suggests that the dominant regressor is more important than the others [61] (p. 233).

Table 4. Dominance analysis: average $\mathrm{R}^{2}$ across sub-sets.

\begin{tabular}{cccc}
\hline Number of Predictors in Model & CSR-1 & CSR-2 & CSR-3 \\
\hline 0 & 0.39 & 0.37 & 0.33 \\
1 & 0.07 & 0.05 & 0.02 \\
2 & 0.05 & 0.02 & 0.00 \\
General dominance & 0.17 & 0.15 & 0.12 \\
Percentage & 39 & 34 & 27 \\
\hline \multicolumn{4}{c}{$n=465}$.
\end{tabular}

We posited in the next hypothesis that employees with high moral attentiveness would be more affected by CSR practices in general than those with low moral attentiveness. To test this, an independent $t$-test was run. The results indicate that there is a significant difference at the 0.001 level between high $(\mathrm{M}=3.97, \mathrm{SD}=1.03, n=243)$ and low $(\mathrm{M}=3.61, \mathrm{SD}=1.120, n=222)$ moral attentiveness. Thus, $\mathbf{H 3}$ is accepted. We also tested for sub-factors of CSR to see if there were any differences (Table 5). Employees with higher moral attentiveness are affected by all sub-groups of CSR more than employees with lower moral attentiveness at the 0.001 and 0.000 levels of significance. Consequently, we accept all the sub-hypotheses (H3a, H3b, H3c).

Table 5. Independent $t$-test results for corporate social responsibility (CSR) sub-groups.

\begin{tabular}{ccccccccc}
\hline \multicolumn{7}{c}{ Moral Attentiveness Group } \\
\hline \multicolumn{7}{c}{ Low $(\boldsymbol{n}=\mathbf{2 2 2})$} & \multicolumn{2}{c}{ High $(\boldsymbol{n}=\mathbf{2 4 3})$} \\
\hline M & SD & M & SD & $\mathbf{9 5 \%}$ CI for Mean Difference & $t$ & df \\
\hline CSR & 3.61 & 1.2 & 3.97 & 1.03 & -0.566 & -0.166 & $-3.59^{* * *}$ & 443.41 \\
CSR-1 & 3.58 & 1.24 & 3.93 & 1.11 & -0.559 & -0.129 & $-3.140^{* *}$ & 444.68 \\
CSR-2 & 3.68 & 1.21 & 4.03 & 1.1 & -0.560 & -0.138 & $-3.245^{* *}$ & 463 \\
CSR-3 & 3.56 & 1.27 & 4.02 & 1.16 & -0.678 & -0.233 & $-4.021^{* * *}$ & 447.99 \\
\hline
\end{tabular}

${ }^{* *} p<0.001 ; * * * 0.000$. CSR-1 = CSR related to employees; CSR-2 = CSR related to society; CSR-3 = CSR related to the natural environment.

H4a proposed that the effects of CSR sub-groups on perceptual moral attentiveness would be different with regards to relative importance. As seen in Table 6, the dominance analysis confirms H4a. Additionally, CSR-3 has the largest dominance value (56\%) for each sub-set of models, which means that it is the completely dominant regressor.

For $\mathbf{H} 4 \mathbf{b}$, we tested whether the effects of CSR sub-groups on reflective moral attentiveness differed with regards to their relative importance. After a dominance regression analysis, the results confirmed our predictions (Table 7). Again, as for H4a, CSR-3 has the largest dominance value (42\%) for each sub-set of models and seems to be the completely dominant regressor here also.

We proposed in $\mathbf{H} \mathbf{5}$ that the employee affective commitment of the employees with high moral attentiveness would be higher than those with lower moral awareness. To verify this, an independent $t$-test was run again. According to the results in Table 8, employees with high moral attentiveness feel 
more affective commitment $(\mathrm{M}=4.01, \mathrm{SD}=0.5)$ at the 0.000 level of significance $(t=-29.382, \mathrm{df}=463$, $p<0.000,95 \%$ CI for mean difference: -1.553 to -1.358$)$. Consequently, $\mathbf{H} 5$ is accepted.

Table 6. Assessment of whether the effect of CSR related to employees, society, and the natural environment on perceptual moral attentiveness would be different with regards to relative importance.

\begin{tabular}{cccc}
\hline Number of Predictors in Model & CSR-1 & CSR-2 & CSR-3 \\
\hline 0 & 0.02 & 0.03 & 0.04 \\
1 & 0 & 0 & 0.01 \\
2 & 0 & 0 & 0.01 \\
General dominance & 0.01 & 0.01 & 0.02 \\
Percentage & 19 & 25 & 56 \\
\hline
\end{tabular}

Table 7. Assessment of whether the effect of CSR related to employees, society, and the natural environment on reflective moral attentiveness would be different with regards to relative importance.

\begin{tabular}{cccc}
\hline Number of Predictors in Model & CSR-1 & CSR-2 & CSR-3 \\
\hline 0 & 0.06 & 0.05 & 0.06 \\
1 & 0.01 & 0 & 0.01 \\
2 & 0 & 0 & 0.01 \\
General dominance & 0.02 & 0.02 & 0.03 \\
Percentage & 32 & 26 & 42 \\
\hline
\end{tabular}

Table 8. Independent $t$-test results for employee affective commitment.

\begin{tabular}{|c|c|c|c|c|c|c|c|c|}
\hline & \multicolumn{4}{|c|}{ Moral Attentiveness Group } & \multirow{3}{*}{\multicolumn{2}{|c|}{ 95\% CI for Mean Difference }} & & \\
\hline & \multicolumn{2}{|c|}{ Low $(n=222)$} & \multicolumn{2}{|c|}{ High $(n=243)$} & & & & \\
\hline & $\mathbf{M}$ & SD & $\mathbf{M}$ & SD & & & $t$ & df \\
\hline AffComm & 2.55 & 0.56 & 4.01 & 0.5 & -1.553 & -1.358 & $-29.382 * * *$ & 463 \\
\hline
\end{tabular}

Our last hypotheses proposed that perceptual moral attentiveness would partially mediate the relationship between CSR-1, -2 , and -3 and affective commitment. To verify this, we first tested the significance of the main indirect effect of perceptual moral awareness, namely that CSR-1, -2 , and -3 would partially explain the levels of employee affective commitment via perceptual moral attentiveness (paths a1b1 $\mathbf{c}^{\prime}{ }_{1}, \mathbf{a} 2 \mathbf{b} 1 \mathbf{c}^{\prime}{ }_{2}$, and $\mathbf{a} 3 \mathbf{b} 1 \mathbf{c}^{\prime}{ }_{3}$ in Figure 1). Table 9 shows that only two of these three-step indirect effects were indeed statistically significant (path a1b1 $\mathbf{c}^{\prime}{ }_{1}=0.0177$, boot $95 \% \mathrm{CI}$ lower $=0.001$, boot $95 \%$ CI upper $=0.0393$; path $\mathbf{a} 2 \mathbf{b} 1 \mathbf{c}^{\prime}{ }_{2}=0.0127$, boot $95 \%$ CI lower $=-0.0061$, boot $95 \%$ CI upper $=0.0354$; path $\mathbf{a} 3 \mathbf{b} 1 \mathbf{c}^{\prime}{ }_{3}=0.0234$, boot $95 \%$ CI lower $=0.0068$, boot $95 \%$ CI upper $\left.=0.0447\right)$. The significant indirect effects between the lower limit confidence interval (bootLLCI) and the upper limit confidence interval (bootULCI) are the ones that do not include zeros (the mediation is partial because the effect of $X$ on $\mathrm{Y}$ is still significant, but there is also a slight drop in coefficient value in the mediation model). Thus, H6a and $\mathbf{H 6 c}$ are accepted, but $\mathbf{H 6 b}$ is rejected.

Table 9. Indirect effect of perceptual moral attentiveness.

\begin{tabular}{cccccc}
\hline Effect & BootSE & BootLLCI & BootULCI & For & Supported \\
\hline 0.0177 & 0.0100 & 0.0001 & 0.0393 & CSR-1 & Yes \\
0.0127 & 0.0107 & -0.0061 & 0.0354 & CSR-2 & No \\
0.0234 & 0.0097 & 0.0068 & 0.0447 & CSR-3 & Yes \\
\hline \multicolumn{7}{c}{$n=465}$.
\end{tabular}

Regarding H6d-f, we posited that reflective moral attentiveness would partially mediate the relationship between CSR-1, -2 , and -3 and affective commitment. By calculating the indirect effects 
using the PROCESS macro 3.1, we checked if CSR-1, -2, and -3 would partially explain the levels of employee affective commitment via reflective moral attentiveness (paths $\mathbf{a} 4 \mathbf{b} \mathbf{2} \mathbf{c}^{\prime}{ }_{1}, \mathbf{a} 5 \mathbf{b} \mathbf{2} \mathbf{c}^{\prime}{ }_{2}$, and $\mathbf{a} \mathbf{6} \mathbf{b} \mathbf{2} \mathbf{c}^{\prime}{ }_{3}$ in Figure 1). Table 10 shows that all of these three-step indirect effects were indeed statistically significant (path $\mathbf{a} 4 \mathbf{b} 2 \mathbf{c}^{\prime}{ }_{1}=0.0163$, boot $95 \%$ CI lower $=0.0041$, boot $95 \%$ CI upper $=0.0328$; path $\mathbf{a} 5 \mathbf{b} 2 \mathbf{c}^{\prime}{ }_{2}=0.0173$, boot $95 \%$ CI lower $=0.0047$, boot $95 \%$ CI upper $=0.0344$; path a6b2 $2 \mathbf{c}^{\prime}{ }_{3}=0.0168$, boot $95 \%$ CI lower $=0.0045$, boot $95 \%$ CI upper $=0.0347)$. All the indirect effects between bootLLCI and bootULCI do not include zeros. Therefore, we accept all the last three sub-hypotheses.

Table 10. Indirect effect of reflective moral attentiveness.

\begin{tabular}{cccccc}
\hline Effect & BootSE & BootLLCI & BootULCI & For & Supported \\
\hline 0.0163 & 0.0074 & 0.0041 & 0.0328 & CSR-1 & Yes \\
0.0173 & 0.0076 & 0.0047 & 0.0344 & CSR-2 & Yes \\
0.0168 & 0.0077 & 0.0045 & 0.0347 & CSR-3 & Yes \\
\hline
\end{tabular}

The overall results of the paths are presented in Figure 2. All the co-efficient values are unstandardized and based on bootstrapping tests.

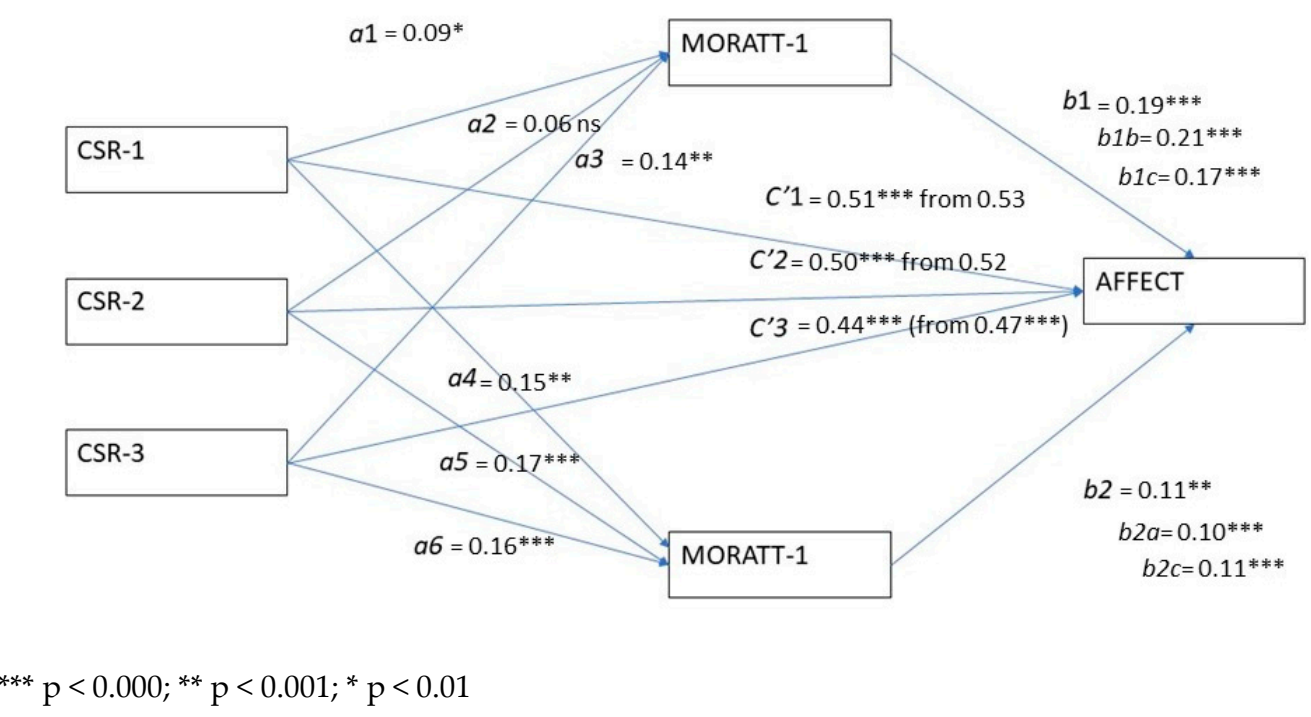

Figure 2. The overall results of the research model.

\section{Conclusions}

Although CSR itself is founded on the moral roots of the society in which it operates $[43,63]$, it seems that the reaction of individuals based on their moral attention has been neglected. Generally, most studies on moral attentiveness have based their models on only one dimension. Unlike the reflective dimension, the perceptual dimension has not been the subject of much empirical research to date. The results of the present paper provide evidence regarding the inclusion of both dimensions. According to Reynolds [25], these two dimensions of moral attentiveness are correlated but they are also conceptually distinct. He argued that perceptually morally attentive individuals screen for and focus on the moral dimensions of information in their daily lives. Therefore, they are more likely to identify a moral pattern or theme in a series of events (e.g., CSR practices) better than others. Reflective moral attentiveness is considered as an intentional response, whereas perceptual moral attentiveness is seen as an automatic response $[49,64]$. As the dominance-analysis results indicate, both dimensions of moral attentiveness have the largest dominance values (56\% and $42 \%$, respectively) with regards to the effects of CSR practices related to the natural environment. However, as the theory posits, perceptually attentive employees tend to be more cognizant of the potentially moral content or consequences of the events around them and, thus, have the largest dominance value. 
A similar response can also be observed for the other CSR practices, though relatively smaller in magnitude. Miao et al. [49] and Wurthmann [22] claimed that prior studies provide stronger evidence regarding the effect of reflective moral attentiveness on ethical decision-making and ethical cognitions than perceptual moral attentiveness. To support their argument, they used Wurthmann's [22] findings as an example, where only the reflective moral attentiveness showed mediation effects between business ethics education and perceptions regarding the importance of ethics and social responsibility. Even Reynolds [25] himself asserted that only reflective moral attentiveness is associated with employees' moral behavior. Thus, like Miao et al. [49], most studies have focused on reflective moral attentiveness, rather than perceptual moral attentiveness. However, as our study has shown, both dimensions of moral attentiveness play important roles in transforming the indirect effects of CSR practices regarding employees' attitudes, such as affective commitment. We can conclude that they are both equally important for organizations. Even when we divided the sample into high/low morally attentive groups and tested whether this grouping might be affected by CSR sub-groups by employing independent $t$-tests, we saw again that employees with high moral attentiveness were more affected by all the sub-groups of CSR practices in their organizations.

To delve deep into which age group has the most effect, we conducted a general linear model test. The effects of age groups 1 (18-25), 2 (26-33), and 3 (34-41) appear to be significant for perceptual attentiveness, and as for reflective attentiveness, only age group 1 appears to be significant. Younger age groups are negatively related to both dimensions of moral attentiveness in our sample. This finding is in parallel with the morality literature. Individuals are expected to develop morality through growth and maturity, and age has been found to correlate with stronger ethical attitudes [65].

Interestingly, former studies have reported positive relationships with females and stronger ethical attitudes than males [66], but we could not find any difference.

Finally, as noted earlier by Baron and Kenny [67], no single mediator is likely to transmit all the effects of a predictor. The literature posits that, to justify a full mediation, "there must be explicit discussion of $\mathrm{M}$ as a conduit of the effect of $\mathrm{X}$ on $\mathrm{Y}^{\prime \prime}$; the conditions for a fully mediated model are "so restrictive that it requires meticulous justification for the notion that $\mathrm{M}$ is the primary reason for the ' $X-Y^{\prime}$ relationship" [55] (p. 689). Based on this assumption, instead of full mediation, we predicted partial mediation for both moral attentiveness dimensions. Consequently, we found enough evidence for the indirect effects of moral attentiveness in this regard.

\subsection{Implications for Practice}

There are some important implications for companies practicing CSR. First, they should keep in mind that CSR is a concept that has the power to influence both external and internal stakeholders (e.g., employees). Most companies prefer to impress externally to create an image for society in general. Internal CSR practices, however, are mostly aimed towards employees. However, as our study and others have revealed, the level of moral attentiveness is not the same for everyone. Thus, one should not expect that every employee will be influenced similarly. Individual differences such as perceptual and reflective moral attentiveness should be taken into consideration. Second, CSR practices in general seem to have a considerable impact in shaping the affective commitment of employees, regardless of their moral attentiveness.

Additionally, as can be drawn from our study, CSR practices aimed only at external stakeholders could even make the employees question the real motives behind those practices, particularly for those with high moral attentiveness. Open communication and sincerity might be the key to resolve such moral dissonances.

Lastly, to increase the moral attentiveness of employees in order to make the most of CSR's effect, interventions and training can be used. For example, Ames et al. [65] found that moral dissonance reduction strategies are a powerful source for effective organizational intervention. Furthermore, they are capable of promoting a workplace where CSR managers, stakeholders, and organizational agents may co-operate and communicate more effectively in ethical decision-making processes. 


\subsection{Implications for Theory}

In recent studies, the focus of CSR activities has shifted towards internal stakeholders. Although limited in number, theoretical models regarding the top-management point of view on CSR practices and how they are affected are increasingly being seen as important. Drawing on theories from a multi-disciplinary perspective, such as the trickle-down effect from economics, explaining the relationships could prove useful in understanding how individuals in every echelon respond differently.

\subsection{Limitations and Suggestions for Future Research}

This study, like most similar studies, is not exempt from limitations. The cross-sectional design prevents us from generalizing the findings. Additionally, it has been argued that the recent pandemic has challenged companies regarding their "commitment to ethical business conduct and CSR" [68] (p. 177). The attempts to profiteer from the crisis in different countries have caused some raised eyebrows and, occasionally, regulatory bodies attempting to dissuade firms from such practices. It would be fruitful to examine the perceptions and attitudes of employees of these firms in the post-pandemic era. The CSR literature is rich in terms of the positive effects of CSR on both external and internal stakeholders. However, as we have attempted to stress in this paper, not every employee perceives their organization's CSR activities the same. There are variations in individuals' reactions to them [69]; for example, how the genuine or political practices of CSR affect employees is worth investigating, as is whether moral standards act as mediators for their perceptions. It will enrich the literature to investigate whether CSR exerts similar or different effects on different employee outcomes, and it still seems important to explain the underlying psychological mechanisms [16].For macrolevel studies, we suggest that scholars examine how emerging multinational firms carry out CSR activities; for example, when they start to operate on foreign soil, whether their CSR activities increase or vary in form. Finally, there is also a criticism regarding the use of only a limited number of theories in forming research models [68]. Researchers are advised to explore beyond social exchange, signaling, and meaningfulness theories; for example, attribution theory has also been suggested [70].

Author Contributions: Data curation, S.U. and S.Y.; Writing—original draft preparation, S.U.; Conceptualization, A.A.; Methodology, A.A.; Writing-review and editing, S.Y. All authors have read and agreed to the published version of the manuscript.

Funding: This research received no external funding.

Conflicts of Interest: The authors declare no conflict of interest.

\section{References}

1. Kuhlman, T.; Farrington, J. What is sustainability? Sustainability 2010, 2, 3436-3448. [CrossRef]

2. Wales, T. Organizational sustainability: What is it, and why does it matter. Review of enterprise and management studies. J. Strateg. Manag. 2013, 1, 41-64.

3. Ji, D.; Liu, Y.; Zhang, L.; An, J.; Sun, W. Green social responsibility and company financing cost-based on empirical studies of listed companies in China. Sustainability 2020, 12, 6238. [CrossRef]

4. Blaga, S. Rethinking business sustainability. Rev. Econ. Stud. Res. 2013, 6, 5-21.

5. Hou, X.; Wang, B.; Gao, Y. Stakeholder protection, public trust, and corporate social responsibility: Evidence from listed SMEs in China. Sustainability 2020, 12, 6085. [CrossRef]

6. Bowen, H.R. Social Responsibilities of the Businessman; University of Iowa Press: Iowa City, IA, USA, 1953.

7. Chen, H.-L.; Hu, Y.-C.; Lee, M.-Y.; Yen, G.-F. Importance of employee care in corporate social responsibility: An AHP-based study from the perspective of corporate commitment. Sustainability 2020, 12, 5885. [CrossRef]

8. Bouraoui, K.; Bensemmane, S.; Ohana, M.; Russo, M. Corporate social responsibility and employees' affective commitment. Manag. Decis. 2019, 57, 152-167. [CrossRef]

9. Friedman, M. The Social Responsibility of business is to increase its profits. Corp. Ethics Corp. Gov. 2007, 13, 173-178. [CrossRef]

10. Orlitzky, M.; Schmidt, F.L.; Rynes, S. Corporate social and financial performance: A meta-analysis. Organ. Stud. 2003, 24, 403-441. [CrossRef] 
11. Porter, M.E.; Kramer, M.R. Creating shared value: How to reinvent capitalism and unleash a wave of innovation and growth. Harv. Bus. Rev. 2011, 62-77.

12. Ollár, A.; Femenías, P.; Rahe, U.; Granath, K. Foresights from the Swedish kitchen: Four circular value opportunities for the built environment. Sustainability 2020, 12, 6394. [CrossRef]

13. Saeed, M.M.; Arshad, F. Corporate social responsibility as a source of competitive advantage: The mediating role of social capital and reputational capital. J. Database Mark. Cust. Strat. Manag. 2012, 19, 219-232. [CrossRef]

14. Lantos, G.P. The boundaries of strategic corporate social responsibility. J. Consum. Mark. 2001, 18, 595-632. [CrossRef]

15. Aguinis, H.; Glavas, A. Embedded versus peripheral corporate social responsibility: Psychological foundations. Ind. Organ. Psychol. 2013, 6, 314-332. [CrossRef]

16. Zhao, X.; Wu, C.; Chen, C.C.; Zhou, Z. The influence of corporate social responsibility on incumbent employees: A meta-analytic investigation of the mediating and moderating mechanisms. J. Manag. 2020. [CrossRef]

17. Ng, T.W.H.; Yam, K.C.; Aguinis, H. Employee perceptions of corporate social responsibility: Effects on pride, embeddedness, and turnover. Pers. Psychol. 2018, 72, 107-137. [CrossRef]

18. Bouraoui, K.; Bensemmane, S.; Ohana, M. Corporate social responsibility and employees' Affective commitment: A moderated mediation study. Sustainability 2020, 12, 5833. [CrossRef]

19. Rupp, D.E.; Shao, R.; Skarlicki, D.P.; Paddock, E.L.; Kim, T.-Y.; Nadisic, T. Corporate social responsibility and employee engagement: The moderating role of CSR-specific relative autonomy and individualism. J. Organ. Behav. 2018, 39, 559-579. [CrossRef]

20. Ditlev-Simonsen, C.D. The Relationship between Norwegian and Swedish employees' perception of corporate social responsibility and affective commitment. Bus. Soc. 2012, 54, 229-253. [CrossRef]

21. Glavas, A. Corporate social responsibility and organizational psychology: An integrative review. Front. Psychol. 2016, 7, 144. [CrossRef]

22. Wurthmann, K. A Social cognitive perspective on the relationships between ethics education, moral attentiveness, and PRESOR. J. Bus. Ethics 2012, 114, 131-153. [CrossRef]

23. Kim, A.; Kim, Y.; Han, K.; Jackson, S.E.; Ployhart, R.E. Multilevel influences on voluntary workplace green behavior: Individual differences, leader behavior, and coworker advocacy. J. Manag. 2014, 43, 1335-1358. [CrossRef]

24. Afsar, B.; Umrani, W.A. Corporate social responsibility and pro-environmental behavior at workplace: The role of moral reflectiveness, coworker advocacy, and environmental commitment. Corp. Soc. Responsib. Environ. Manag. 2019, 27, 109-125. [CrossRef]

25. Reynolds, S.J. Moral attentiveness: Who pays attention to the moral aspects of life? J. Appl. Psychol. 2008, 93, 1027-1041. [CrossRef] [PubMed]

26. Sun, L.; Yu, R. The impact of corporate social responsibility on employee performance and cost. Rev. Account. Financ. 2015, 14, 262-284. [CrossRef]

27. Schaefer, S.D.; Terlutter, R.; Diehl, S. Talking about CSR matters: Employees' perception of and reaction to their company's CSR communication in four different CSR domains. Int. J. Advert. 2019, 39, 191-212. [CrossRef]

28. Meyer, J.P.; Becker, T.E.; Vandenberghe, C. Employee commitment and motivation: A conceptual analysis and integrative model. J. Appl. Psychol. 2004, 89, 991-1007. [CrossRef]

29. Turker, D. Measuring Corporate social responsibility: A scale development study. J. Bus. Ethics 2008, 85, 411-427. [CrossRef]

30. Meyer, J.P.; Herscovitch, L. Commitment in the workplace: Toward a general model. Hum. Resour. Manag. Rev. 2001, 11, 299-326. [CrossRef]

31. Bedük, A.; Kılınç, S. The Relationship of organizational justice and organizational commitment: An example of milk and dairy product company. Glob. J. Hum. Resour. Manag. 2015, 3, 1-13.

32. Mercurio, Z.A. Affective commitment as a core essence of organizational commitment. Hum. Resour. Dev. Rev. 2015, 14, 389-414. [CrossRef]

33. Afsar, B.; Maqsoom, A.; Shahjehan, A.; Afridi, S.A.; Nawaz, A.; Fazliani, H. Responsible leadership and employee's proenvironmental behavior: The role of organizational commitment, green shared vision, and internal environmental locus of control. Corp. Soc. Responsib. Environ. Manag. 2020, 27, 297-312. [CrossRef] 
34. Meyer, J.P.; Maltin, E.R. Employee commitment and well-being: A critical review, theoretical framework and research agenda. J. Vocat. Behav. 2010, 77, 323-337. [CrossRef]

35. Kanter, R.M. Commitment and social organization: A study of commitment mechanisms in Utopian communities. Am. Sociol. Rev. 1968, 33, 499. [CrossRef]

36. Sheldon, M.E. Investments and involvements as mechanisms producing commitment to the organization. Adm. Sci. Q. 1971, 16, 143. [CrossRef]

37. Rego, A.; Leal, S.; Cunha, E.M.P. Rethinking the employees' perceptions of corporate citizenship dimensionalization. J. Bus. Ethics 2011, 104, 207-218. [CrossRef]

38. Lin, C.-P.; Lyau, N.-M.; Tsai, Y.-H.; Chen, W.-Y.; Chiu, C.-K. Modeling corporate citizenship and its relationship with organizational citizenship behaviors. J. Bus. Ethics 2010, 95, 357-372. [CrossRef]

39. Folger, R. Fairness as deonance. In Theoretical and Cultural Perspectives on Organizational Justice; Gilliland, S., Steiner, D.D., Skarlicki, D., Eds.; Information Age: Greenwich, CT, USA, 2001; pp. 3-33.

40. Turker, D. How Corporate social responsibility influences organizational commitment. J. Bus. Ethics 2008, 89, 189-204. [CrossRef]

41. Steger, M.F.; Dik, B.J.; Duffy, R.D. Measuring meaningful work. J. Career Assess. 2012, 20, 322-337. [CrossRef]

42. Bright, D.S.; Winn, B.A.; Kanov, J. Reconsidering virtue: Differences of perspective in virtue ethics and the positive social sciences. J. Bus. Ethics 2013, 119, 445-460. [CrossRef]

43. Lampert, M. Corporate social responsibility and the supposed moral agency of corporations. Ephemer. Theory Politics Organ. 2016, 16, 79-105.

44. Taufik, D.; Bolderdijk, J.W.; Steg, L. Acting green elicits a literal warm glow. Nat. Clim. Chang. 2014, 5, 37-40. [CrossRef]

45. Hameed, I.; Riaz, Z.; Arain, G.A.; Farooq, O. How do internal and external CSR affect employees' organizational identification? A perspective from the group engagement model. Front. Psychol. 2016, 7, 788. [CrossRef] [PubMed]

46. Rest, J.; Navarez, D. Moral Development in the Professions: Psychology and Applied Ethics; Erlbaum: Hillsdale, NJ, USA, 1994.

47. Tso, I.F.; Grove, T.B.; Taylor, S.F. Emotional experience predicts social adjustment independent of neurocognition and social cognition in schizophrenia. Schizophr. Res. 2010, 122, 156-163. [CrossRef] [PubMed]

48. Dawson, D. Organisational virtue, moral attentiveness, and the perceived role of ethics and social responsibility in business: The case of UK HR practitioners. J. Bus. Ethics 2015, 148, 765-781. [CrossRef]

49. Miao, Q.; Eva, N.; Newman, A.; Nielsen, I.; Herbert, K. Ethical leadership and unethical pro-organisational behaviour: The mediating mechanism of reflective moral attentiveness. Appl. Psychol. 2019, 69, 834-853. [CrossRef]

50. Van Laer, T.; De Ruyter, K.; Cox, D. A Walk in customers' shoes: How attentional bias modification affects ownership of integrity-violating social media posts. J. Interact. Mark. 2013, 27, 14-27. [CrossRef]

51. Zulaifah, E.; Uyun, Q.; Witruk, E.; Gaol, F.; Hutagalung, F.; Peng, C.; Isa, Z.; Rushdan, A. Testing the spillover and crossover effect of work-family interference on the personal and family domain among families with work separation. In Trends and Issues in Interdisciplinary Behavior and Social Science; Informa UK Limited: Jogjakarta, Indonesia, 2017; pp. 175-182.

52. Martin, S. The Role of Moral Identity in Newcomers' Socialization. Ph.D. Thesis, Cornell University, Ithaca, NY, USA, 2013.

53. Rest, J.R. Moral Development: Advances in Research and Theory; Praeger: New York, NY, USA, 1986.

54. Kohlberg, L. Moral stages and moralization: The cognitive-developmental. In Moral Development and Behavior: Theory, Research and Social Issues; Lickona, T., Ed.; Holt, Rinehart and Winston: New York, NY, USA, 1976.

55. Holland, S.J.; Shore, D.B.; Cortina, J.M. Review and recommendations for integrating mediation and moderation. Organ. Res. Methods 2016, 20, 686-720. [CrossRef]

56. Rockwood, N.J.; Hayes, A.F. Mediation, Moderation, and Conditional Process Analysis. In The Cambridge Handbook of Research Methods in Clinical Psychology; Wright, A.G.C., Hallquist, M.N., Eds.; Cambridge University Press (CUP): Cambridge, UK, 2020; pp. 396-414.

57. El Akremi, A.; Gond, J.-P.; Swaen, V.; De Roeck, K.; Igalens, J. How do employees perceive corporate responsibility? Development and validation of a multidimensional corporate stakeholder responsibility scale. J. Manag. 2015, 44, 619-657. [CrossRef] 
58. Allen, N.J.; Meyer, J.P. The Measurement and Antecedents of Affective, Continuance and Normative Commitment. J. Occup. Psychol. 1990, 63, 1-18. [CrossRef]

59. Gok, K.; Sumanth, J.J.; Bommer, W.H.; Demirtas, O.; Arslan, A.; Eberhard, J.; Ozdemir, A.I.; Yigit, A. You may not reap what you sow: How employees' moral awareness minimizes ethical leadership \& rsquo; positive impact on workplace deviance. J. Bus. Ethic. 2017, 146, 257-277. [CrossRef]

60. Budescu, D.V. Dominance analysis: A new approach to the problem of relative importance of predictors in multiple regression. Psychol. Bull. 1993, 114, 542-551. [CrossRef]

61. Darlington, R.B.; Hayes, A.F. Regression Analysis and Linear Models: Concepts, Applications, and Implementation; Guilford Publications: New York, NY, USA, 2016.

62. Kath, L.M.; Stichler, J.F.; Ehrhart, M.G.; Sievers, A. Predictors of nurse manager stress: A dominance analysis of potential work environment stressors. Int. J. Nurs. Stud. 2013, 50, 1474-1480. [CrossRef] [PubMed]

63. Tamvada, M. Corporate social responsibility and accountability: A new theoretical foundation for regulating CSR. Int. J. Corp. Soc. Responsib. 2020, 5, 1-14. [CrossRef]

64. Reynolds, S.J.; Owens, B.P.; Rubenstein, A.L. Moral stress: Considering the nature and effects of managerial moral uncertainty. J. Bus. Ethics 2011, 106, 491-502. [CrossRef]

65. Ames, J.; Bluhm, D.; Gaskin, J.; Lyytinen, K. The impact of moral attentiveness on manager's turnover intent. Soc. Bus. Rev. 2020. [CrossRef]

66. Borkowski, S.C.; Ugras, Y.J. Business students and ethics: A meta-analysis. J. Bus. Ethics 1998, 17, 1117-1127. [CrossRef]

67. Baron, R.M.; Kenny, D.A. The moderator-mediator variable distinction in social psychological research: Conceptual, strategic, and statistical considerations. J. Pers. Soc. Psychol. 1986, 51, 1173-1182. [CrossRef]

68. He, H.; Harris, L. The impact of Covid-19 pandemic on corporate social responsibility and marketing philosophy. J. Bus. Res. 2020, 116, 176-182. [CrossRef]

69. Aguinis, H.; Glavas, A. On corporate social responsibility, sensemaking, and the search for meaningfulness through work. J. Manag. 2017, 45, 1057-1086. [CrossRef]

70. Glavas, A.; Radic, M. Corporate social responsibility: An overview from an organizational and psychological perspective. Oxf. Res. Encycl. Psychol. 2019. [CrossRef]

(C) 2020 by the authors. Licensee MDPI, Basel, Switzerland. This article is an open access article distributed under the terms and conditions of the Creative Commons Attribution (CC BY) license (http://creativecommons.org/licenses/by/4.0/). 